\title{
Greening up in logistics: Managerial perceptions of small and medium-sized enterprises on sustainability in Zimbabwe
}

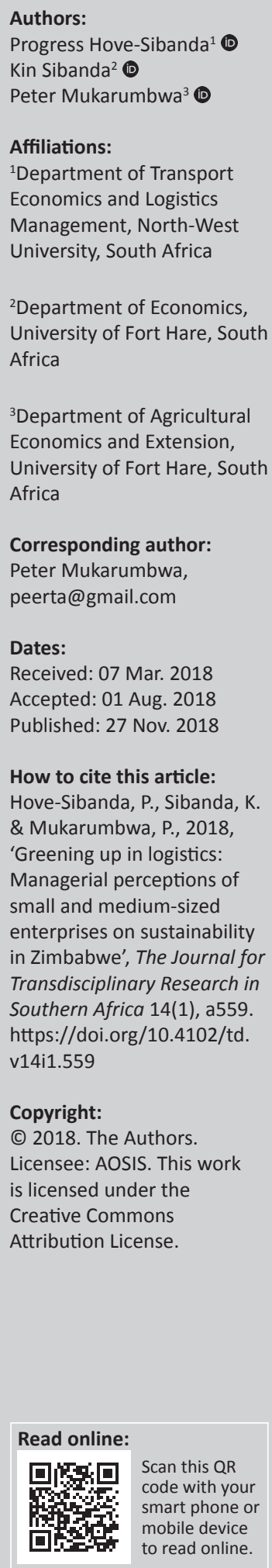

Authors:

Kin Sibanda ${ }^{2}$

Affiliations:

Department of Transport Management, North-West University, South Africa

${ }^{2}$ Department of Economics, University of Fort Hare, South University of Fort Hare, South Africa

author: Peter Mukarumbwa

Dates:

Received: 07 Mar. 2018 Accepted: 01 Aug. 2018

How to cite this article: Hove-Sibanda, P., Sibanda, K. Mukarumbwa, P., 2018, Managerial perceptions of small and medium-sized enterprises on sustainability in Zimbabwe', The Journal for theriplinary Resear https://doi.org/10.4102/td. v14i1.559

Copyright: Licensee: AOSIS. This work is licensed under the Creative Commons Attribution License.
'Sustainability' and 'going green' have become buzzwords in today's business world. In logistics, greening up in a sustainable way in the future suggests the need to identify innovative measures that go beyond merely reducing carbon emissions. The purpose of this article was to explore managerial perceptions on green logistics barriers, applications and the importance of green logistics in Zimbabwean small and medium-sized enterprises (SMEs). A qualitative research approach that utilised semi-structured interviews to collect data from five SME managers and one government official was used. Using a thematic deductive line-by-line content analysis approach, this article principally found that internal barriers such as costs, lack of resources and knowledge are major barriers impeding the adoption and application of green logistics in Zimbabwean SMEs. Poor infrastructure and roads were reported to be the common external barriers of green logistics adoption in SMEs. The article also found that most of the participant SMEs in Zimbabwe were not yet applying green logistics, although some were striving towards practising packaging optimisation, warehousing, inventory management optimisation, along with transport optimisation and efficiency (particularly, route optimisation and fuel efficiency). From the themes, the study found that green logistics is important to the few environmentally conscious SMEs. The importance of green logistics identified were the creation of brand loyalty, good brand image, the possibility of attracting government support, cost saving, as well as improving the firm's profitability in the long run. Conclusions were drawn and recommendations to both firms and government were made.

\section{Introduction}

Given the highly competitive environment that companies now operate in, green logistics issues have become important for the sustainability of enterprises (Chhabra, Garg \& Singh 2018; ElBerishy, Rügge \& Scholz-Reiter 2013; Ubeda, Arcelus \& Faulin 2011; Xuezhong, Linlin \& Chengbo 2011). Such issues are even more paramount to small and medium-sized enterprises (SMEs) because their viability is constantly threatened by fierce competition from sizeable corporate entities. However, studies focusing on green logistics, particularly in the case of SMEs, are limited. According to Srivastava (2007) studies in green logistics only started gaining prominence in the literature as an important economic and social subject in the 1990s. This emanated from environmental regulations as well as consumer demands that emerged in the early 1990s, prompting companies to attach an environmental component to their supply chain management (Srivastava 2007; Wu \& Dunn 1995). Environmental issues are intertwined with logistical decisions leading to complexities in supply chain processes, such as transport planning, sourcing of raw material, modal selection and location inter alia (Ebinger, Goldbach \& Schneidewind 2006; Wu \& Dunn 1995). Since then numerous attempts have been made towards examining green logistics using different theories and perspectives. Nevertheless, there is a dearth of literature on case studies in general and specifically those that scrutinise the importance of green logistics focusing on managerial perceptions of SMEs. Studies that connect logistical issues such as packaging, distribution, procurement and reserve logistics to averting environmental harm are present, yet literature that specifically captures theoretical concepts of green logistics management is scarce (Lai \& Wong 2012). Therefore, according to Chhabra et al. (2018) green logistics research is still in its initial stages, particularly in Zimbabwe.

Meanwhile, the discourse on environmental damages emanating from increased industrial activities has gained momentum in the international arena (Economy \& Lieberthal 2007; Kolk \& Pinkse 2008). Thus, the importance of green logistics management for averting environmental harm springing from manufacturing products and distribution activities has become more urgent 
because of globalisation (Chhabra et al. 2018; Dekker, Bloemhof \& Mallidis 2012; Lai \& Wong 2012). The implementation of green logistics management is regarded as an opportunity by manufacturing companies to align their operations to international good practices on resource conservation and to attain environmental profitability (Abduaziz et al. 2015; Jedliński 2014; Lai \& Wong 2012). Moreover, interest from companies, government and the general public in adopting green logistics is increasing because of the fact that traditional logistics are failing to satisfy the needs of modern society, resulting in massive environmental impacts (Denisa \& Zdenka 2015; SerokaStolka 2014). Hence, new ways need to be found to overcome these environmental challenges and to attain the desired goal of market competition.

The need to attain an economic competitive advantage in the global market places pressure on companies to operate in a more efficient and effective manner (Speranza 2018). This view is true particularly for SMEs because of their need to remain viable, expand and withstand competition from large companies through taking advantage of business opportunities and harnessing technological advances. Adoption of green logistics is envisaged as one way that can offer such sustainability and provide SMEs with positive business reputations (Denisa \& Zdenka 2015; Mangla, Kumar \& Barua 2015). Consequently, benefits accruing from implementing green practices by SMEs can lead to increased market share and ultimately higher profits (Chhabra et al. 2018; Rao \& Holt 2005; Šatanová \& Sedliačiková 2014).

Enterprises with managers who support green logistics are deemed to be more 'proactive and eco-innovative' (SerokaStolka 2016). Additionally, these companies tend to have a competitive advantage and attain a leading role in their businesses (Seroka-Stolka 2016). However, in the SMEs' logistics processes the development of environmental issues is still viewed as being in the preliminary stages. Moreover, within the Zimbabwean context, little is known about managerial perceptions on green logistics particularly in the SME fraternity. From the foregoing, it is not surprising that in 2016, Zimbabwe's Logistics Performance Index was ranked at 151 out of 160 countries (Arvis et al. 2016).

The draft Strengthening National Capacity for Climate Change Report (2013) revealed that the transport sector emitted $12 \%$ of greenhouse gases in 2013 (which was expected to grow with time as the sector grew). The same report also called for:

'... transport policies to be amended to encourage low-carbon transport, for the redefinition of emissions standards for vehicles, for strengthening capacity to monitor and measure vehicle emissions and to enforce emissions standards, for promotion of vehicle maintenance and for the promotion of 'cleaner' fuels such as ethanol and natural gas'. (Government of Zimbabwe Ministry of Environment, Water and Climate 2018: 115)
In September 2017, Zimbabwe's Minister of Energy, Samuel Undenge changed the cap from 500 parts per million to a cap of:

‘50 parts per million maximum sulfur content in diesel fuel which is in line with the country's National Energy Policy in terms of reducing vehicle emissions and improving air quality'. (Ministry of Energy and Power Development, National Energy Policy 2017: 11)

The changes were to apply as from 01 November 2017. Whilst all these caps and modifications continue to be made to policy, the main problem in Zimbabwe lies with the efficacy in implementation and enforcement of these policies, such as the National Energy Policy, along with the Environmental Management Act (EMA). Further, the EMA is not as visible in urban areas as it is in rural regions. As such, a detailed study is warranted on the barriers that hinder green logistics in urban SMEs, as well as the application and importance of green logistics.

Small and medium-sized enterprises play a vital role in the economic development of many countries around the world, and the situation is no different for Zimbabwe. However, definitions for SMEs differ from country to country (Huang, Tan \& Ding 2015; Makanyeza \& Dzvuke 2015). Small and medium-sized enterprises in this study refers to any formal or informal small and medium enterprise concerned with any economic business activity employing fewer than 100 employees on a full-time basis (Small Enterprise Development Cooperation 2011). This study uses Sanchez and Lafuente's (2010:736-737) definition of 'environmental consciousness', which refers to the 'expression of feelings' by SME owners or managers 'of their moral obligation combined with their willingness along with their capability to protect the environment'. In other words, environmentally conscious SME owners or managers proactively concern themselves with their willingness and ability to protect and improve the environment in all their day-to-day running of the business and in all logistics activities. On the one hand, environmentally conscious SME owners or managers are concerned with attaining a differential competitive advantage through going green in all logistics and business activities. On the other hand, cost-conscious SME owners or managers assume a rather passive role when it comes to protecting the environment because they prefer to externalise the responsibility and cost to improve the environment. Their concern is primarily on achieving cost advantages by minimising operational costs, and they are unwilling to pay for any extra costs, especially when it comes to going green in logistics activities.

Small and medium-sized enterprises contribute significantly to the Zimbabwean economy, accounting for approximately 90\% of employment (Makanyeza \& Dzvuke 2015; Manyani et al. 2014). It is estimated that SMEs contribute towards $60 \%$ of carbon dioxide and $70 \%$ of all industrial pollution globally (Parker, Redmond \& Simpson 2009). Nevertheless, because SMEs mainly perceive themselves as causing negligible environmental impacts in relation to large firms, they 
generally lag behind in the adoption of sustainability as an important issue (Battisti \& Perry 2011; Masurel 2007). Hence, most SMEs focus on daily survival, which trumps the adoption of green practices (Ashton, Russell \& Futch 2017). However, because of the large number of SME firms in Zimbabwe and the pivotal influence that they exert on the environment, attention needs to be paid to their impact. Hence, SMEs are highly significant in green logistics as they cause extensive environmental degradation. Currently, literature on large companies and green logistics is beginning to emerge, yet little is known about SMEs and green logistics globally and specifically in Zimbabwe. Minimal studies focusing on SMEs and green logistics have been undertaken (see, e.g., Denisa \& Zdenka 2015; Huang et al. 2015; Piaralal et al. 2015). This scarcity in research concentrating on the adoption of green practices by SMEs warrants undertaking such an analysis.

The rest of the article is structured as follows. Firstly, it provides the context of the study and then provides a review of the relevant literature explaining the adoption of green logistics. This is followed by research objectives. Following the research objectives is a discussion pertaining to the qualitative research approach used in this study. This is followed by the presentation of results of the survey. Finally, conclusions and policy implications are offered.

\section{Context}

\section{Green logistics and management of small and medium-sized enterprises in Zimbabwe}

Literature on SME adoption of green logistics in Zimbabwe is limited. However, deficiencies in the managerial skills of SMEs in Zimbabwe have been attributed as one of the factors derailing the successful embracement of green logistics in operations. Numerous scholars support the notion that SMEs in Zimbabwe lack basic managerial functions such as leading, planning, organising and controlling (Dumbu \& Chadamoyo 2012; Karedza et al. 2014; Musanzikwa 2014). Additionally, another facet considered deficient is financial management. These scholars have noted that most SMEs in Zimbabwe fail to adhere to professional and commercial practices in business management operations. For example, manual, rather than electronic, accounting records are maintained. Such constraints lead to poor performance and stifle the growth of SMEs in the country. Notwithstanding these challenges, the government through the Small Enterprise Development Corporation has created initiatives that aim to develop the human capital base among SMEs that are specifically targeted at owners or managers (Chigwenya \& Mudzengerere 2013). A wide range of courses such as management, cooperative governance, record keeping, production skills and stock taking are offered. Affiliations have also been created by the Zimbabwean government between the Standards Association of Zimbabwe and SMEs to try and assure the competitiveness and quality of goods produced by SMEs. It should however be noted that these efforts are still in their infancy and as a result not many SMEs have yet managed to tap into and benefit from these initiatives. Furthermore, aspects specifically focused on equipping SME managers with environmental management techniques (such as green logistics) are presently minimal to non-existent. This is exacerbated by the fact that SMEs in Zimbabwe generally lack appreciation for green management as a branding tool (Chigora \& Zvavahera 2015). Moreover, in a study carried out among tourism SMEs in Gweru by Nyahunzvi (2014), results revealed that SMEs lacked formal environmental policies and that managers had limited awareness regarding green logistics.

\section{Sustainability of small and medium-sized enterprises in Zimbabwe}

Many SMEs in Zimbabwe exhibit limited business sustainability and upward mobility. This situation emanates from unfriendly regulation and policy environments, the harsh macroeconomic domain as well as poor managerial skills. As such, the majority of SMEs in Zimbabwe are categorised as being in a survivalist business mode (Research Continental-Fonkom and FinMark Trust 2012). Using a sample of 282 SME employees (obtained from Harare), Chinomona and Dhurup (2014) found a positive association between the quality of work life and job commitment, employee job satisfaction and ultimately tenure intention. It is envisaged that green logistics can assist SME sustainability in Zimbabwe by increasing employee job commitment, job satisfaction and tenure. The majority of SMEs in Zimbabwe operate in working conditions that are far below governmentstipulated safety standards (Chinomona et al. 2010). This both threatens viability and dampens employee morale and job satisfaction. Failure to adopt appropriate technologies (such as green logistics) was identified by Chipangura (2012) as one of the major factors constraining SME growth in Zimbabwe. Again, the sustainability of SMEs in Zimbabwe is threatened by financial exclusion and the cumbersome process of obtaining licences and permits. Similarly, product and organisational innovation were also found to have a positive bearing on SME development in Zimbabwe (Makanyeza \& Dzvuke 2015). Against this backdrop, it is suggested that the adoption of green management practices by Zimbabwe's SMEs can go a long way towards enhancing sustainable development. Furthermore, the training of SME managers and other employees on green logistics can be an important focal point towards improving sustainability.

\section{Literature review}

Green logistics can be viewed as one of the most important subcomponents of green supply chain activities (Zaman \& Shamsuddin 2017). Recently it has taken centre stage because of the need to expand to new markets, globalisation, customer demands and market competition (Isaksson et al. 2011). Green logistics is still regarded as a relatively new concept and its meaning is ever evolving.

There are numerous definitions of the concept of green logistics, with many variations. Green logistics is defined as the study of practices that endeavour to attain a sustainable balance between environmental, economic and social 
objectives by decreasing environmental externalities such as noise and accidents, as well as greenhouse gas emissions (Chhabra et al. 2018; Dekker et al. 2012; Zhang \& Zhao 2012). Sustainability development can only be attained in a business if a balance is achieved between these three components, as illustrated in Figure 1. The diagram shows the interaction between different factors and that sustainability can only be attained in the middle as a common result.

According to Chang and Qin (2008), 'green logistics' is geared towards reducing environmental harm by undertaking activities such as implementing current logistics techniques and planning and controlling the flow of logistics. This flow must satisfy customer needs and reduce environmental damage. Thus, green logistics entail the capability of an institution to offer products and services that both attain economic efficiency and are environmentally friendly (Chhabra et al. 2018). 'Green logistics' can also refer to the ability of an organisation to meet the social needs of ecological preservation through increased work efficiency, decreasing waste and conserving resources (Lai \& Wong 2012). Hence, green logistics concentrate on reducing environmental hazards such as noise, accidents and greenhouse gas emissions (Chhabra et al. 2018). Sbihi and Eglese (2010) add to this dimension by defining green logistics as a sustainable way to produce and distribute products and services, taking into consideration social and environmental factors. Despite these variations there seems to be a general consensus that green logistics is mainly concerned with business activities that minimise costs whilst upholding environmental, social and economic goals. As a result, from a business perspective, if adopted by SMEs the benefits that can accrue are numerous.

\section{Relationship between green logistics and sustainability}

Enterprises are driven to adopt green practices by various factors, which include, but are not limited to, increasing competitive advantage, enhancing customer relationships and reducing business costs (El-Berishy et al. 2013). Hence, sustainable development can only be achieved if there is a

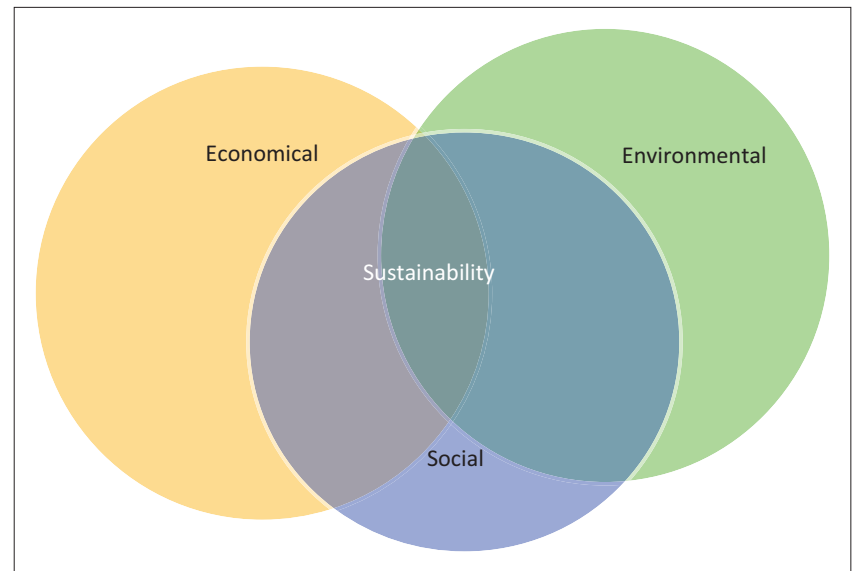

Source: Adapted from Carter, C.R. \& Rogers, D.S., 2008, 'A framework of sustainable supply chain management: Moving toward new theory', International Journal of Physical Distribution \& Logistics Management 38(5), 360-387. https://doi. org/10.1108/ 09600030810882816

FIGURE 1: Relationship between green logistics and socio-economic environmental factors. balance between the environment, society and the economy as illustrated in Figure 1. Green logistics enable coordination of activities so that a balance is attained by enterprises between the three priorities of environmental, economic and social concerns (Jedliński 2014). Therefore, implementation of green logistics enables enterprises to become sustainable. Sustainability is concerned with SMEs being able to operate profitably in the long run. Thus, sustainable economic growth can be achieved through environmentally friendly use of renewable resources and proper management of natural resources to attain business objectives using green technologies (Jedliński 2014).

\section{Challenges and barriers in implementation of green logistics by small and medium-sized enterprises}

Perceptions and responses of managers towards green logistics initiatives occupy an important role in enterprise environmental policies (Seroka-Stolka 2016). Managers who lack commitment to taking up green logistics practices will resultantly observe such behaviour being transmitted to employees, thus also discouraging workers from implementing these initiatives (Seroka-Stolka 2016). Therefore, a lack of managerial support concerning the adoption of green logistics can be one of the major implementation challenges facing SMEs. Additionally, Denisa and Zdenka (2015) offer the following as some of the main barriers that hinder SMEs from successfully implementing green logistic activities, based on a study conducted in Slovakia:

- finance and economic factors

- customers who are unwilling to pay for green logistic initiatives and whose requirements are not clear.

The above factors are also supported by the findings of Chan (2008), who identified that managers who lacked the following act as barriers to implementation of green logistics practices:

- knowledge and skills

- professional advice

- resources.

These findings were based on an exploratory analysis from a sample of 83 hotel managers. Nevertheless, to the authors' best knowledge empirical studies that specifically focus on barriers to implementation of green logistics by SMEs in Zimbabwe are minimal to non-existent.

Notwithstanding the aforementioned challenges, pressure has recently been mounting for SMEs to implement ethical codes, which can enhance the surrounding business environment (Šatanová \& Sedliačiková 2014). According to Denisa and Zdenka (2015), as well as Seroka-Stolka (2016), for SMEs to attain environmental sustainability, green logistics initiatives need to be factored into corporate strategies earlier on, which might enable implementation towards the whole enterprise. Equally important, the development of green logistics in enterprises requires that managers actively promote International Organisation for 
Standardization (ISO) 14000 international standards (Zhang \& Zhao 2012). Research findings from Chinese logistics companies reiterated the importance of state legal regulations, human resource quality and organisational support in positively influencing the adoption of green practices (Lin \& Ho 2010). Similarly, compliance with ISO 14001 standards, which are recognised worldwide, is regarded as one of the drivers for the adoption of green practices within enterprises (Diabat \& Govindan 2011; Hasan \& Chan 2014; Seroka-Stolka 2016). For example, Huang et al. (2015) stated that Chinese manufacturing SMEs are increasingly under pressure from both local and foreign customers to comply with ISO 14001 standards. Ultimately, this will improve products and services offered. More importantly, human resource development regarding green logistics at all SME levels needs to be a top priority. This can assist SMEs in obtaining a competitive advantage, gaining customer loyalty and satisfying corporate needs (Denisa \& Zdenka 2015).

\section{Environmental legislative framework of small and medium-sized enterprises in Zimbabwe}

Environmental regulatory legislations are important if enterprise products are to withstand competition in markets that are regulated (Gunasekaran, Lai \& Edwin Cheng 2008; Lai \& Wong 2012). Such environmental regulatory legislation, enacted by both local and international bodies, is mainly aimed at controlling environmental damages emanating from company activities such as production, transportation and disposal of the product (Lai \& Wong 2012). Zimbabwe enforces environmental sustainability for the activities of both large firms and SMEs through the EMA (Chapter 20:27) (Parliament of Zimbabwe 2002). Thus, for example, all SMEs involved in projects that are categorised as first schedule under the EMA (Chapter 20:27), namely ore processing, housing development and mining, are required to conduct an Environmental Impact Assessment (EIA). An EIA is a process that assists in identifying environmental impacts of a development project and clearly outlines measures to mitigate these negative effects during the project's life cycle. Thus firms, regardless of size, are obliged to work in accordance with the EMA statutes, which are aligned with the ISO statutes that encourage enterprises to go green. However, as noted earlier the problem in Zimbabwe mostly lies with enforcement of the EMA. Further, the EMA is not as visible in urban areas compared to rural regions. This therefore justifies the need for a detailed study on the barriers that hinder green logistics in urban SMEs, the application of and the importance of green logistics.

\section{Research objectives}

This article explored the following:

- small and medium-sized enterprises' managerial perceptions as well as their opinions on barriers that hinder adoption and implementation of green logistics activities

- managerial perceptions on the green logistics activities practised, if any, by SMEs in Zimbabwe
- managerial perceptions of SMEs on the importance of green logistics in Zimbabwe.

To the authors' best knowledge, no such study has yet been undertaken in Zimbabwe. Hence, the findings of this study will assist in expanding the literature on the subject matter as well as policymaking on decreasing the environmental impact from logistical activities of SMEs in the country.

\section{Methodology}

This study followed a qualitative research approach, as this enabled the researchers to aptly seek answers to research questions posed through examining the various social settings (the Zimbabwean SME sector) and the perceptions of managers who occupy the SME sector in Zimbabwe. More specifically, the qualitative research methodology permitted the researchers to explore managerial perceptions and gain insight into the barriers of green logistics, the application of green logistics activities among Zimbabwean SMEs and the importance of green logistics to the SMEs' clients. The current study thus tapped into the strengths of qualitative research such as naturalism, flexibility of use and the fact that findings are more reliable, though this comes with the shortfall of non-generalisability of results obtained (Cooper \& Schindler 2006; Kumar 2011).

\section{Data}

According to Maree (2016):

sample sizes in qualitative research depends [sic] on what the researcher(s) wants to know, the purpose of the inquiry, what is at stake, what will be useful, what will have credibility, and what can be done with available time and resources. (p. 84)

Maree (2016) further stipulates that for homogeneous samples, eight participants will yield credible results, provided that the saturation point has been reached. Previous qualitative studies on green logistics such as that by Göransson, Gustafsson and Lindbergh (2014), as well as Hijaz et al. (2015), used sample sizes of five and six, respectively, with both studies yielding credible results.

In the current study, initially, 20 SMEs in the logistics industry based in the Chegutu and Harare urban areas were contacted by email and telephonically to schedule interview appointments. However, only 10 of these SMEs responded favourably and allowed for interviews to be scheduled. Two of these SMEs thereafter cancelled the scheduled interviews for business-related reasons. All in all, five SME managers and one government official were interviewed. This is because after evaluating the data collection process, it was recognised that the saturation point was reached for the SMEs at the fifth interview. Thus, at this point (i.e. at interview number 5) it was perceived that there was nothing new or significant that could be obtained from orchestrating any further interviews with the remaining SME managers. However, an additional interview with a government official 
was then conducted to ensure credibility and trustworthiness of the collected data from the SMEs.

As shown in Table 1, interviewees comprised SME managers (five in total). Experience ranged from 6 to 15 years, whilst educational qualifications were in Agriculture, Agricultural Business, Auto-Mechanics, Marketing and Economics. The lowest qualification discerned was a national certificate, with the highest being a Master of Commerce. As shown in Table 1, the SME managers interviewed all possessed more than 5 years of experience and held post-secondary school qualifications. This suggests all the interviewees selected were both competent and fit for the purposes of this study.

\section{Data collection and interviewing}

Data in this study was collected through semi-structured interviews. Using semi-structured interviews enabled the right balance between uniformity in questions asked (which ensured that there was order during all interviews) and freedom for the interviewer and interviewee (Creswell 2014). Further, as argued by Creswell $(2009,2014)$, using semistructured interviews enabled exploration of green logistics issues in SMEs, a problem that is fairly new, particularly in Zimbabwe, where less research has been conducted in this regard. On average, the interviews took 30-45 min each and were carried out in English. An interview guide was created with open-ended questions structured into three main categories: (1) green logistics barriers; (2) green logistics activities application; and (3) importance of green logistics. Where necessary, additional (follow-up) questions were asked, especially when it was realised that the responses given were too vague for discerning what the interviewee's intended reply was. Before each interview, each SME was thoroughly researched. This enabled the assurance of quality in the data collected. Consent to record the interviews from each interviewee was also sought. Notes were taken during interviews to supplement and complement transcribed texts.

\section{Transcribing}

All the interviews were recorded and transcribed. In cases where notes and the transcribed text were too vague, raised questions or posed the possibility of misinterpretation, interviewees were contacted for clarity by either email or telephone.

TABLE 1: Small and medium-sized enterprises and interviewee profile.

\begin{tabular}{lllcl}
\hline $\begin{array}{l}\text { Company } \\
\text { number }\end{array}$ & $\begin{array}{l}\text { Size of company } \\
\text { or type of } \\
\text { organisation }\end{array}$ & $\begin{array}{l}\text { Position of } \\
\text { interviewee }\end{array}$ & $\begin{array}{c}\text { Years of } \\
\text { experience } \\
\text { in logistics }\end{array}$ & $\begin{array}{l}\text { Educational } \\
\text { background }\end{array}$ \\
\hline 1 & Medium & $\begin{array}{l}\text { Marketing } \\
\text { manager }\end{array}$ & 10 & $\begin{array}{l}\text { Diploma in } \\
\text { Agriculture }\end{array}$ \\
\hline 2 & Small & Manager & 6 & BSc in Agri-Business \\
\hline 3 & Medium & $\begin{array}{l}\text { Product } \\
\text { manager }\end{array}$ & 6 & MCom in Economics \\
\hline 4 & Small & Manager & 15 & $\begin{array}{l}\text { National certificate in } \\
\text { Auto-Mechanics and } \\
\text { previously worked as } \\
\text { a workshop foreman }\end{array}$ \\
\hline 5 & Small & Manager & 8 & BCom in Marketing \\
\hline 6 & Government & Senior & 7 & MCom in Economics \\
\hline
\end{tabular}

SME, small and medium-sized enterprises.

\section{Data analysis}

A thematic, deductive, line-by-line content analysis approach was followed to analyse data in this study. The data analysis was in four stages. Firstly, themes derived from previous relevant literature on green logistics were created. As earlier noted, three main themes were created, namely barriers to green logistics, green logistics activities application and the importance of green logistics. Secondly, because a deductive approach to analyse data was followed, the transcribed interview text was separated into sentences and paragraphs. This allowed for a line-by-line content analysis of the data. Thirdly, each sentence or paragraph was allocated a close code from the list of themes derived from literature.

Because a word document was utilised, different colours were used to highlight the various themes accordingly. For instance, for the green logistics barriers the following was used: Bright green = costs; red $=$ lack of knowledge on green logistics; yellow = red tape or absence of a green logistics framework or legislation to enforce compliance; pink = lack of resources; blue = technological challenges; grey = lack of political will; teal = poor infrastructure or poor roads; violet = customers' unwillingness to pay for green activities; and turquoise $=$ lack of incentives.

This was followed by cutting and pasting all the quotes for each theme and bringing them together. In this fourth stage, the themes and subthemes that emerged were examined, with the aim of assessing how each of these subthemes and themes related to one another. This process was repeated and checked for new emerging themes. It was at this stage that network diagrams were used to show the hierarchical relationships between the different ideas, themes and emerging subthemes. Use of a radial or spider diagram was also incorporated to show how each item or topic (barrier) linked to the central item (green logistics barriers among SMEs).

\section{Verification, credibility and trustworthiness}

To ensure authenticity, credibility and trustworthiness of the results in this study, interviewees were consulted during member checking (Maree 2016). Specifically, the interviewees were asked to read and review the draft of the transcribed text and the first draft of the report, so that they could further elaborate on, change or confirm the analysis conducted. Further, to ensure credibility and dependability of the results, a government official who works with SMEs and environmental issues was interviewed and corroborated the responses obtained from the SMEs.

\section{Results and discussion}

The findings in this study are presented in three sections, as informed by the research objectives: Barriers to green logistics in SMEs, green logistics activities application and the importance of green logistics. 


\section{Barriers to green logistics in small and medium-sized enterprises}

The first objective in this article sought to ascertain the managerial perceptions on the barriers that hinder the adoption and application of green logistics activities in Zimbabwe. To achieve this objective, the following question was asked: From a managerial point of view, what barriers hinder SMEs from adopting and applying green logistics in Zimbabwe?

Despite the economic role played by SMEs in Zimbabwe, particularly through job creation and poverty alleviation, such entities still lag behind when it comes to environmental consciousness in activities. Figures 2 and 3 present the barriers inhibiting SMEs in Zimbabwe from adopting and applying green logistic activities in the day-to-day running of businesses.

Figure 3 provides a hierarchical analysis of these barriers. As shown in Figure 3, analysis of the logistics barriers resulted in two subcategories, namely key and secondary barriers. These were further subdivided into major internal barriers, common internal and external barriers, as well as other secondary internal and external barriers to green logistics in SMEs.

Most of the interviewees (four SME managers and one government official) unequivocally and strongly emphasised that costs, ranging from investment costs to operating and certification costs (key internal barriers), were a major hindrance in the adoption and application of green logistics in business activities. In addition, half (three out of six) of the interviewees cited lack of resources, lack of knowledge on green logistics and its importance, along with technology challenges, as common internal barriers. Poor infrastructure

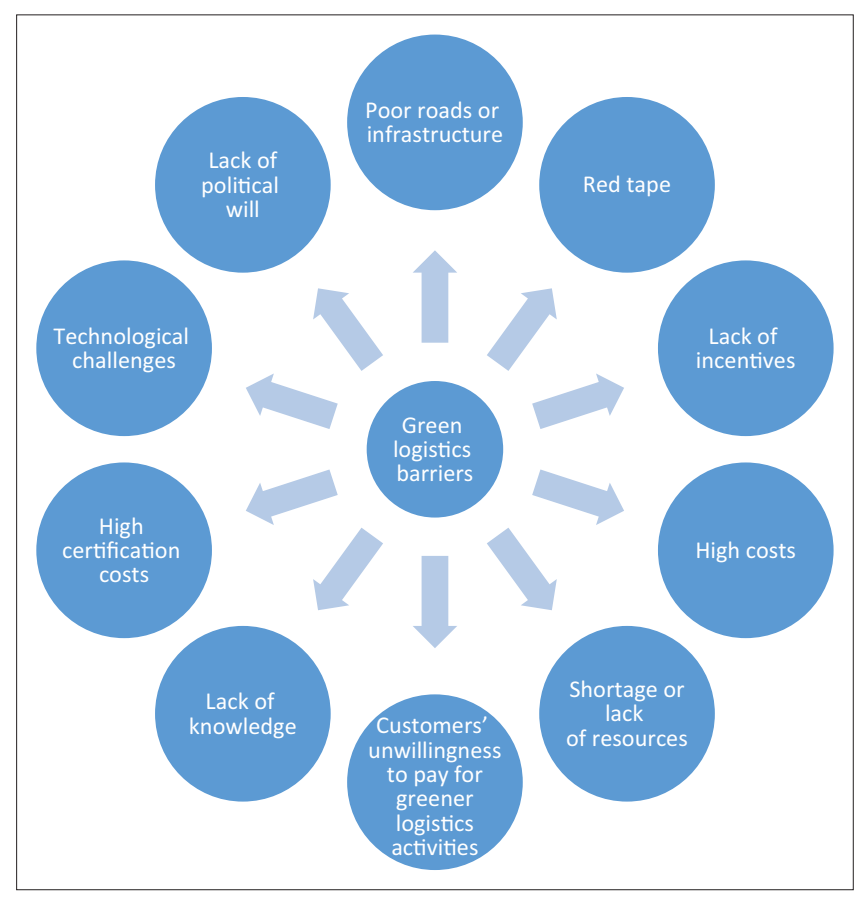

FIGURE 2: A green logistics barrier web diagram. was cited as a common external barrier to green logistics application in SMEs. One male small firm manager, with eight years of experience in the logistics industry, specifically stated: 'Poor infrastructure and very poor roads are a major hindrance. Bad roads result in low speed, more fuel consumption and increased logistics costs'. Another male interviewed product medium firm manager with six years of experience in the logistics industry further elaborated:

'Most roads in Zimbabwe are in a bad state, currently full of potholes and motorists are forced to drive at slower speed. This results in higher fuel consumption and high carbon emissions into the environment. At this rate, transportation can only concern themselves about the operational costs such as maintaining the damaged vehicles and fuel costs, while ignoring the need to go green'. (Participant 3, male, 52 years old, Product manager)

In a way, costs are a key barrier to green logistics application caused by poor infrastructure or roads. Thus, in line with the above quotes, poor roads lead to fuel inefficiency and traffic congestion because of low speeds, which ultimately leads to higher carbon emissions.

Of the three subcategories of green logistics barriers, the barriers least cited by the SME managers interviewed included other secondary internal barriers (the absence of a green logistics framework) and external barriers (namely, red tape, no legislation to enforce compliance, no incentives, no political will and customers' unwillingness to pay extra costs for greening up). These findings corroborate previous studies such as those by Chan (2008), Göransson et al. (2014), Denisa and Zdenka (2015), as well as Piaralal et al. (2015), who found investment costs, customers' priorities and unwillingness to pay extra to be the barriers to green logistics in firms.

\section{Application of green logistics activities}

The second objective in this article sought to explore managerial perceptions on the green logistics activities, if any, practised by SMEs in Zimbabwe. To achieve this objective, the following questions were asked: From a managerial point of view, do SMEs apply any green logistics activities? If so, why? If not, why? And which logistics activities are practised in these SMEs? Tables 2 and 3 present the findings on whether green logistics activities are applied by SMEs in daily operations and the specific green logistics being applied.

As shown in Table 2, green logistics is not yet applied by most Zimbabwean SMEs. From the responses given by the SME managers interviewed, one thing is clear: There are those that are not yet applying it, whilst there are some SME managers that are not sure if their firms are indeed applying green logistics. For instance, two of the SME managers interviewed stated: 'Green logistics is not really applied in their firms'. Such responses could mean that these managers were not sure whether green logistics activities were applied in their firm; they could mean that these managers were not directly involved with the operations incorporating green 


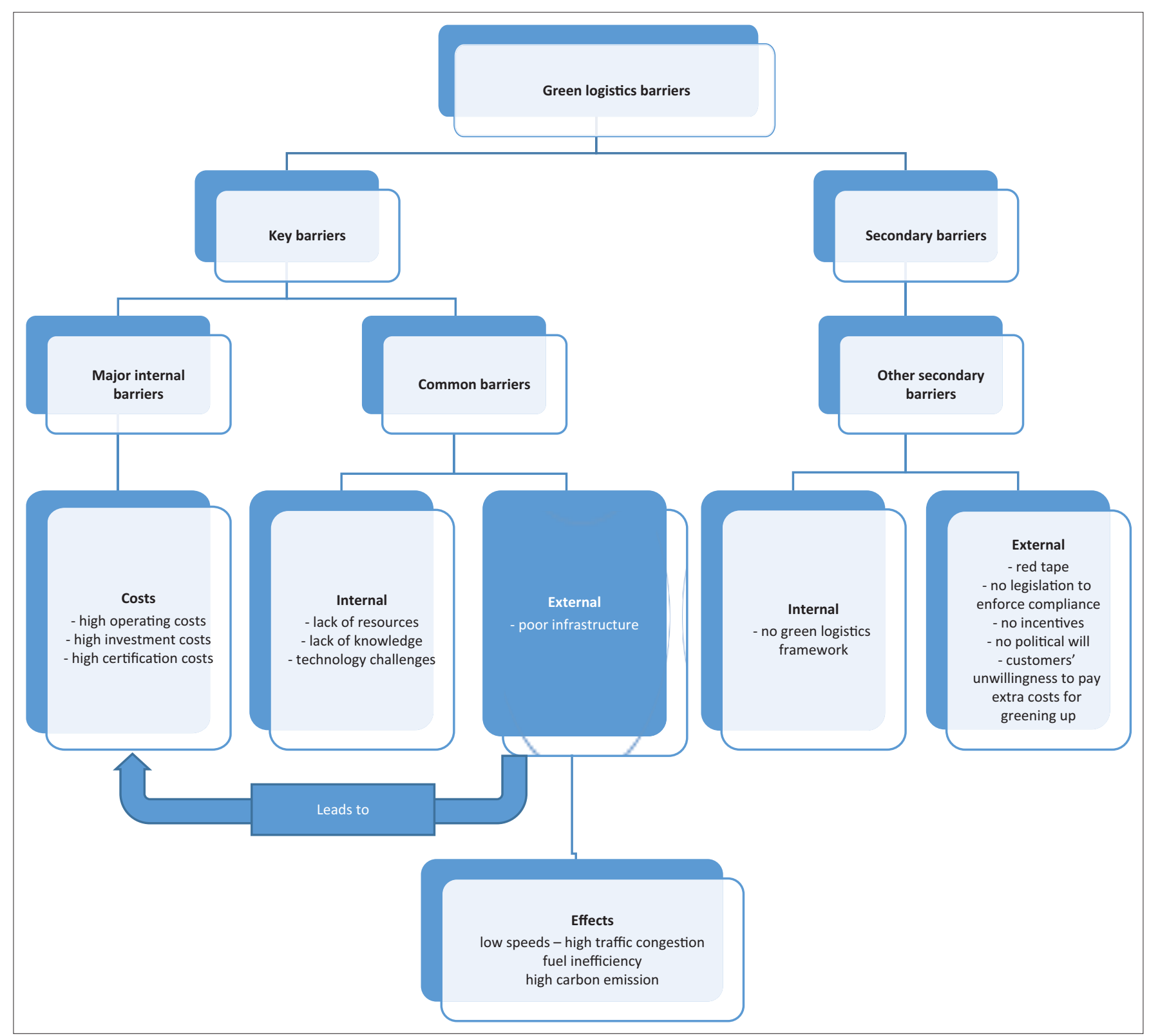

FIGURE 3: A hierarchical analysis of green logistics barriers.

TABLE 2: Application and reasons for green logistics application in small and medium-sized enterprises.

\begin{tabular}{|c|c|c|}
\hline Company & Applied or not? & Reason \\
\hline 1 & Not really applied & $\begin{array}{l}\text { - Companies shy away to avoid increasing operating } \\
\text { costs, because they are currently preoccupied with } \\
\text { reducing operating costs }\end{array}$ \\
\hline 2 & Not yet applied & $\begin{array}{l}\text { - Companies are hesitant to apply green logistics } \\
\text { because it might increase operating costs }\end{array}$ \\
\hline 3 & Not really applied & $\begin{array}{l}\text { - Companies lack the required resources and lack } \\
\text { education on green logistics }\end{array}$ \\
\hline 4 & No, they are not & $\begin{array}{l}\text { - At present companies are ignorant of the concept } \\
\text { of green logistics } \\
\text { - Legislation is lacking or the momentum is weak } \\
\text { - Of course EMA is there but implementation is the } \\
\text { problem }\end{array}$ \\
\hline 5 & Not applied & $\begin{array}{l}\text { - The situation in Zimbabwe is not conducive to } \\
\text { anything that will attract extra costs. We are } \\
\text { currently struggling to stay afloat }\end{array}$ \\
\hline 6 & $\begin{array}{l}\text { To a great } \\
\text { extent, they do } \\
\text { not apply it }\end{array}$ & $\begin{array}{l}\text { - They do not have enough overhead to manage } \\
\text { green logistics } \\
\text { - High costs are associated with going green } \\
\text { - There is a lack of knowledge and education on } \\
\text { green logistics and its benefits } \\
\text { - There is a lack of government monitoring of the } \\
\text { implementation of the ISOs on sustainability }\end{array}$ \\
\hline
\end{tabular}

EMA, Environmental Management Act. logistics; it could be that their firms were at an advanced stage of planning to apply them or that the firm was not aware of what green logistics was all about. From the interviews conducted, one of the reasons given by a male auto-mechanic, who has managed a small firm for the past 15 years in the logistics industry, to support the response provided was:

'Uhmm ... I have mixed feelings about this. Most of us are not well educated about green logistics and what good it can bring to our businesses. You know what, though some might be aware of green logistics but they are without a sound understanding of the concept and its benefits'. (Participant 4, male, 40 years old, Auto-mechanic)

Given the economic hardships in Zimbabwe, the chances are that even the government's priorities are on other issues that could help improve the financial crisis, which explains the laxity when it comes to emphasising and 
enforcing the environmental responsibilities of firms, irrespective of their size.

After having consulted literature on some of the green logistics activities applied by firms and comparing it with the actual meaning of green logistics, SME managers included in the study then were asked about the activities currently applied in their firm. The activities were grouped into transport optimisation and efficiency (which consisted of the following sub-activities: Fuel efficiency, route optimisation, load optimisation, measuring and reducing carbon emissions), reverse logistics, packaging optimisation, procurement, warehousing and inventory management (see Tables 3 and 4). As shown in Tables 3 and 4, some of the SMEs are striving towards practising green logistics, particularly in transport route optimisation and fuel efficiency, as well as optimisation of packaging, warehousing and inventory management.

Most of the SME managers interviewed believed that reverse logistics was not practised and half of these felt that little or no effort was put towards load optimisation nor towards measuring and reducing carbon emissions. For instance, one male medium firm product manager who holds a postgraduate qualification in Economics, with six years of experience in the logistics industry, pointed out:

'No, we are not yet practising green logistics. As we speak there are still old model cars that are allowed to make unnecessary trips, more often these vehicles are usually overloaded, which pollutes the environment the more and consumes more fuel. Most companies do not service their vehicles'. (Participant 3, male, 52 years old, Product manager)

From this it can be deduced that indeed load optimisation, fuel efficiency, along with measuring and reducing carbon emissions, are still not practised.
Another male marketing manager of a medium-sized logistics firm with 10 years of experience in the logistics industry stated:

‘Well, as I have earlier said, due to economic hardships companies are cutting costs and compromising on green activities. Some companies, for instance, are using cheaper fuels, unsustainable packaging, and their waste management is very poor. I think we have a very long way to go before companies could fully implement green logistics'. (Participant 1, male, 37 years old, Marketing manager)

Likewise, a male, auto-mechanic by profession, small firm manager with 15 years of experience in the logistics industry also stated:

'You see, some companies might be striving to comply with most of these activities, but carbon emission measurement might not be applied in most companies if not all due to lack of the proper technology and its cost implications'. (Participant 4, male, 40 years old, Auto-mechanic)

From the two preceding quotes, it seems SMEs are blaming lagging behind in green logistics implementation on economic hardships, lack of proper technology and the cost implications thereof. This makes sense, given that in 2016 the Logistics Performance Index ranked Zimbabwe 151 out of 160 countries (Arvis et al. 2016). This alone indicates that Zimbabwean companies are lagging behind in terms of various logistical aspects. Given that green logistics is a fairly new concept, countries that are poor performers, such as Zimbabwe, are expected to be found still lagging behind in this regard.

\section{The importance of green logistics}

The last objective in this article sought to ascertain the managerial perceptions of SMEs on the importance of green logistics in

TABLE 3: Green logistics activities practised by Zimbabwean small and medium-sized enterprises.

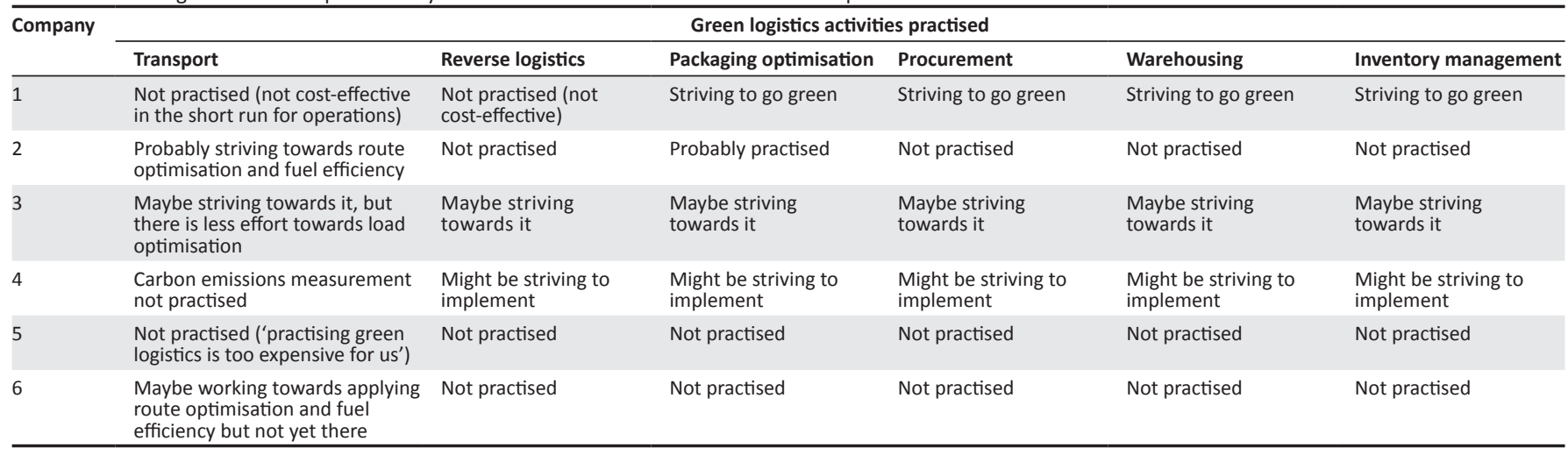

TABLE 4: Green logistics activities practised.

\begin{tabular}{|c|c|c|c|c|}
\hline Green logistics activities & Not practised & Probably practised & Striving towards practising & Maybe striving towards practising \\
\hline $\begin{array}{l}\text { Transport optimisation and } \\
\text { efficiency }\end{array}$ & $\begin{array}{l}\text { - Load optimisation } \\
\text { - Measuring and reducing carbon emissions } \\
\text { - Half of the participants }(3 / 6)\end{array}$ & - & $\begin{array}{l}\text { - Fuel efficiency } \\
\text { - Few of the participants }(2 / 6)\end{array}$ & $\begin{array}{l}\text { - Route optimisation } \\
\text { - Half of the } \\
\text { - participants }(1 / 6)\end{array}$ \\
\hline Reverse logistics & - Majority of the participants $(4 / 6)$ & - & - Few $(2 / 6)$ & - \\
\hline Packaging optimisation & - Few $(2 / 6)$ & - Few $(1 / 6)$ & - Half $(3 / 6)$ & - \\
\hline Procurement & - Half $(3 / 6)$ & - Few (1/6) & - Few $(2 / 6)$ & - \\
\hline Warehousing optimisation & - Half $(3 / 6)$ & - & - Majority (3/6) & - \\
\hline
\end{tabular}


Zimbabwe. To achieve this objective, the interviewees were asked the following questions: Of what importance is green logistics to you and your clients? Why? Figure 4 provides a hierarchical analysis of the importance of green logistics.

As can be discerned from Figure 4, green logistics is important to the few elite who understand it. However, to the majority, green logistics is regarded as 'not important'. Two subcategories emerged from the responses given by the interviewees: (1) the environmentally conscious and (2) the cost-conscious.

The cost-conscious believe that green logistics is not important as it tends to increase extra and unnecessary costs and that the technology and cleaner fuels required may increase operational costs. As one male small firm manager, with an agricultural business qualification, who has six years of experience in the logistics industry opined:

'Green logistics is not important. The larger scale firms in logistics are also not doing enough. They are also part of the companies who procure second-hand vehicles from Japan, which increases the carbon emission levels. Rarely can you find a company in Zimbabwe that goes for cleaner fuels such as the Jatrofa, as they claim that Jatrofa is too weak for their vehicles'. (Participant 2, male, 36 years old, Manager).

Taking into consideration the above quote, it is possible to state that the reason cleaner fuels are perceived to be weak, and increasing costs, is because vehicles are not well maintained and most are old, second-hand vehicles. Moreover, considering that the roads in Zimbabwe are in a very poor state, the cost-conscious are bound to view green logistics as an unnecessary cost, and as attracting the free rider problem. In other words, to the cost-conscious, companies are not willing to incur the expense of going green but want to enjoy the benefits at the expense of the few who are environmentally conscious. This defeats the whole purpose of going green in logistics. Cost-conscious firms believe that the economic hardships experienced in the country are the root cause of the negative light in which green logistics are viewed.

Contrary to what cost-conscious firms believe, environmentally conscious firms are of the view that green

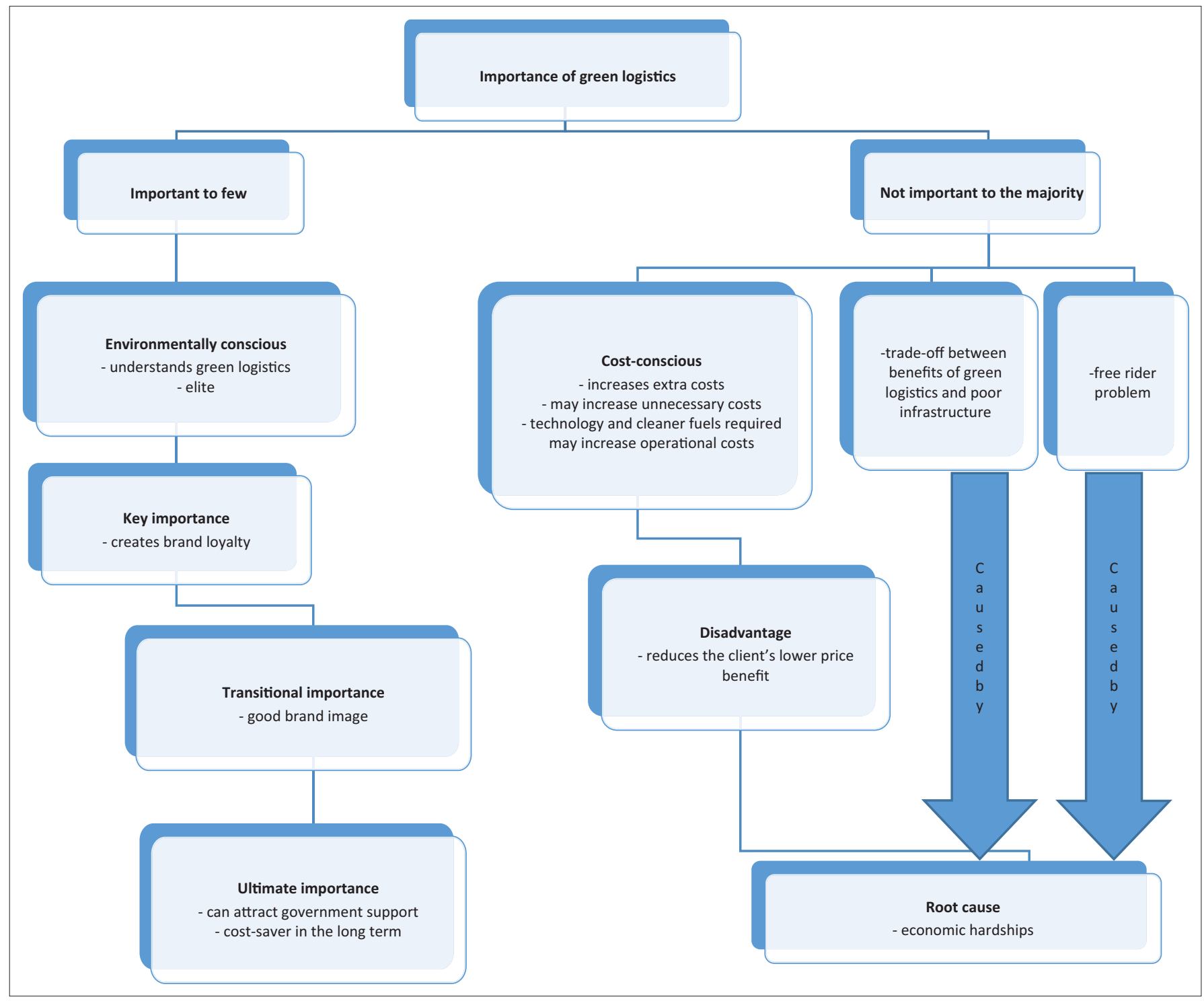

FIGURE 4: A hierarchical analysis of the importance of green logistics. 
logistics is important both in the short and long-term. Key to note is the fact that environmentally conscious firms believe that green logistics application can create brand loyalty among clients. This will lead to the creation of a good brand image for environmentally conscious firms, which can ultimately attract government support, serve as a cost-saver and improve profits in the long run. In other words, cost saving is not a priority to environmentally conscious firms. Rather, a competitive advantage lies in caring for the environment. As such, cost saving is just an added advantage.

\section{Conclusion}

The current study explored managerial perceptions on the major themes and barriers that hinder SMEs from adopting and applying green logistics, the application of green logistics activities and the importance of green logistics to SMEs and clients. The major conclusion of this article is that costs, lack of resources and knowledge are the key internal barriers, whilst poor infrastructure and roads are common external barriers to green logistics adoption by SMEs in Zimbabwe. The article also concluded that whilst most SMEs are not yet applying green logistics activities, there are some that are striving towards practising packaging optimisation, warehousing, inventory management optimisation, along with transport optimisation and efficiency (particularly route optimisation and fuel efficiency). The study further concludes that the creation of brand loyalty, good brand image, the possibility of attracting government support and cost saving, as well as improving the firm's profitability in the long run, constitute the importance of green logistics to the few environmentally conscious SMEs.

\section{Recommendations}

In light of the above findings and conclusions, this article recommends the following:

\section{To the Zimbabwean firms (small and medium-sized enterprises)}

In order to mitigate the barriers to green logistics adoptions, the SMEs need to:

- Provide education and training: Firms should send employees to formal and informal courses to keep abreast of best practices of green logistics implemented by other companies globally. Benchmarking is still an effective tool. Firms also need to see what other companies are excelling at and challenge themselves to improve in such areas, especially green transportation.

In order for the SMEs to appreciate the benefits and importance of green logistics, SMEs need to:

- cultivate an organisational culture of going green

- conduct awareness campaigns that reveal the environmental importance and benefits of green logistics.
In order for green logistics practices to evolve further in Zimbabwe, the SMEs need to:

- Go green in terms of all logistical activities, regardless of firm size.

- Firms should be encouraged to procure vehicles that use cleaner fuels, such as Jatrofa, a tried-and-tested, cleaner fuel in Zimbabwe. Firms also need to be well informed on the benefits of using cleaner fuels. This will help reduce carbon emissions and even cut down on the costs in the long run because Jatrofa fuel is relatively cheaper. Small and medium-sized enterprises are also advised to avoid buying second-hand vehicles, as these tend to do more harm than good to the environment. Additionally, firms also need to maintain vehicles better and get these serviced frequently.

- Firms should use recommended load size for vehicles properly, use shorter routes, use experienced drivers and cut down on unnecessary trips. Small and medium-sized enterprises need to cut down on the number of trips by ensuring that no half-load trips are made but instead come up with ways to encourage full-load trips, whilst finding alternative routes and using Jatrofa, as it is a cleaner yet cost-effective fuel available in Zimbabwe. Firms should also avoid overloading vehicles, as this leads to increased carbon emissions.

- Firms need to use disposable and reusable packaging.

- Develop a green logistics framework that can serve as a guideline in green logistics application in the firm.

- Form collaborations and long-term partnerships with larger firms that are already implementing green logistics activities successfully, be it locally or globally.

- Companies should have internal policies that emphasise green logistics at every angle and should not think in the short term as this will discourage entities from going green. Instead, companies should reflect on the long-term benefits that they stand to gain should green logistic activities be implemented. Further, companies should incorporate green logistics in policies and goals as part of corporate social responsibilities.

- Engage all stakeholders: There is need for an allstakeholder engagement from the suppliers, manufacturers, transporters, retailers down to the final customer.

\section{To the Zimbabwean government}

In order for green logistics to evolve further in Zimbabwe, the Government of Zimbabwe needs to:

- Benchmark: The government should benchmark and constantly revise environmental laws and also enforce these in the form of fines to the non-compliant. Although benchmarking is currently administered, perhaps as a once-off thing, there is need for the government to constantly benchmark with the best-performing countries across the globe and to revise laws respectively.

- Incentivise: The government needs to incentivise those who comply and punish offenders for green logistics to be a success. Precisely, the government should cut taxes 
and provide tax breaks to firms that comply with green logistics as an incentive. In addition, the government should also subsidise and have education programmes (be they formal or informal) on green logistics.

- Enforce green logistics policies: Based on the findings of this study, the enforcement of policies in Zimbabwe appears to be problematic. As such, there is a need to ensure that green logistics policies in place are effectively enforced. For instance, the Zimbabwean government can start with enforcing the scrapping of old second-hand gasoline cars. This will help the country to reduce emissions. Whilst infrastructural differences are acknowledged, it is still imperative that the Zimbabwean government enforce the scrapping of old gasoline cars and perhaps shift the cut-off year to 2000. This will complement the recent cap of 50 parts per million for diesel placed by the Zimbabwean Minister of Energy.

\section{Acknowledgements}

The authors wish to thank the Govan Mbeki Research Development Centre, University of Fort Hare and the NorthWest University Research Department for financial assistance. They would like to extend a word of appreciation to all the participants in this study for availing themselves and for all their contributions.

\section{Competing interests}

The authors declare that they have no financial or personal relationships that may have inappropriately influenced them in writing this article.

\section{Authors' contributions}

P.H.S., K.S. and P.M. contributed equally to this work. P.H.S., K.S. and P.M. conceptualised and designed the study. P.H.S. and K.S. analysed the data. P.H.S., K.S. and P.M. wrote and proofread the article.

\section{References}

Abduaziz, O., Cheng, J.K., Tahar, R.M. \& Varma, R., 2015, 'A hybrid simulation mode for green logistics assessment in automotive industry', Procedia Engineering 100 960-969. https://doi.org/10.1016/j.proeng.2015.01.455

Arvis, J.-F., Saslavsky, D., Ojala, L., Shepherd, B., Busch, C., Raj, A. et al., 2016, Connecting to compete: Trade logistics in the global economy: The logistics performance index and its indicators, World Bank, Washington, DC, viewed 19 July 2018, from http://lpi.worldbank.org/international/global.

Ashton, W., Russell, S. \& Futch, E., 2017, 'The adoption of green business practices among small US Midwestern manufacturing enterprises', Journal of Environmental Planning and Management 60(12), 2133-2149. https://doi.org/10.1080/0964056 8.2017.1281107

Battisti, M. \& Perry, M., 2011, 'Walking the talk? Environmental responsibility from the perspective of small-business owners', Corporate Social Responsibility and Environmental Management 18(3), 172-185.

Carter, C.R. \& Rogers, D.S., 2008, 'A framework of sustainable supply chain management: Moving toward new theory', International Journal of Physical Distribution \& Logistics Management 38(5), 360-387. https://doi. org/10.1108/09600030810882816

Chan, E.S.W., 2008, 'Barriers to EMS in the hotel industry', International Journal of Hospitality Management 27(2), 187-196. https://doi.org/10.1016/j. ijhm.2007.07.011

Chang, Q. \& Qin, R., 2008, 'Analysis on development path of tianjin green logistics', International Journal of Business and Management 3(9), 96-98.

Chhabra, D., Garg, S.K. \& Singh, R.K., 2018, 'Analyzing alternatives for green logistics in an Indian automotive organization: A case study', Journal of Cleaner Production 167, 962-969. https://doi.org/10.1016/j.jclepro.2017.02.158.
Chigora, F. \& Zvavahera, P., 2015, 'Be green and you are branded: Case of small to medium enterprises in Zimbabwe tourism sector', Journal of Entrepreneurship and Business Innovation 2(1), 1-13.

Chigwenya, A. \& Mudzengerere, F.H., 2013, 'The small and medium enterprises policy in Zimbabwe: A narrative of strides taken to mainstream the informal sector activities in urban local authorities in Zimbabwe', International Journal of Politics and Good Governance 4(4), 1-18, viewed 23 January 2018, from http://www. onlineresearchjournals.com/ijopagg/art/139.pdf

Chinomona, R. \& Dhurup, M., 2014, 'The influence of the quality of working life on employee job satisfaction, job commitment and tenure intention in the SME sector in Zimbabwe', South African Journal of Economic and Management Sciences 17(4), 363-378.

Chinomona, R., Lin, J.Y.C., Wang, M.C.H. \& Cheng, J.M.S., 2010, 'Soft power and desirable relationship outcomes: The case of Zimbabwean distribution channels', Journal of African Business 11(2), 182-200. https://doi.org/10.1080/15228916.20 10.508997

Chipangura, A., 2012, 'Growth constraints of small and medium enterprises (SMEs) at Glenview Furniture Complex (GFC) in Harare (Zimbabwe)', International Journal of Marketing and Technology 2(6), 40-83. http://www.ijmra.us

Cooper, D. \& Schindler, P., 2006, Marketing research, McGraw-Hill, New York.

Creswell, J.W., 2009, Research design: Qualitative, quantitative and mixed methods approaches, 3rd edn., Sage, London, viewed 18 February 2018, from https:// www.inderscienceonline.com/doi/abs/10.1504/IJBIS.2015.067264.

Creswell, J.W., 2014, Research design: Qualitative, quantitative and mixed methods approaches, 4th edn., Sage, London.

Dekker, R., Bloemhof, J. \& Mallidis, I., 2012, 'Operations research for green logistics An overview of aspects, issues, contributions and challenges', European Journal of
Operational Research 219(3), 671-679. https://doi.org/10.1016/j. Operational Rese

Denisa, M. \& Zdenka, M., 2015, 'Perception of implementation processes of green logistics in SMEs in Slovakia', Procedia Economics and Finance 26(15), 139-143. https://doi.org/10.1016/S2212-5671(15)00900-4

Diabat, A. \& Govindan, K., 2011, 'An analysis of the drivers affecting the implementation of green supply chain management', Resources, Conservation and Recycling 55(6), 659-667. https://doi.org/10.1016/j.resconrec.2010.12.002

Dumbu, E. \& Chadamoyo, P., 2012, 'Managerial deficiencies in the small and medium enterprises (SMEs) in the craft industry: An empirical evidence of SMEs at Great Zimbabwe in Chief Mugabe's area', European Journal of Business and Management 4(10), 79-86. https://doi.org/10.4038/suslj.v6i1.1692

Ebinger, F., Goldbach, M. \& Schneidewind, U., 2006, 'Greening supply chains: A competence-based perspective', in J. Sarkis (ed.), Greening the supply chain, pp. 251-269, Springer, New York.

Economy, E. \& Lieberthal, K., 2007, 'Scorched earth: Will environmental risks in China overwhelm its opportunities?', Harvard Business Review 85(6), 88-96.

El-Berishy, N., Rügge, I. \& Scholz-Reiter, B., 2013, 'The interrelation between sustainability and green logistics', in 16th IFAC conference on management and control of production and logistics, pp. 527-531, Fortaleza, September 11-13, The International Federation of Automatic Control. https://doi.org/10.3182/20130911 3-BR-3021.00067

Göransson, H., Gustafsson, S. \& Lindbergh, L., 2014, Green logistics in South Africa: A study of the managerial perceptions in the road transportation industry in South Africa, Umea University, Umea, Sweden. SE-901 87.

Government of Zimbabwe Ministry of Environment, Water and Climate 2018, National Climate Change Response Strategy, viewed 19 July 2018, from www.ies.ac.zw/ downloads/draft $\% 20$ strategy.pdf

Gunasekaran, A., Lai, K.-H. \& Edwin Cheng, T.C., 2008, 'Responsive supply chain: A competitive strategy in a networked economy', Omega 36(4), 549-564. https:// doi.org/10.1016/j.omega.2006.12.002

Hasan, M. \& Chan, C.K., 2014, 'ISO 14000 and its perceived impact on corporate performance', Business and Management Horizons 2(2), 1. https://doi. org/10.5296/bmh.v2i2.6546

Hijaz, S., Al-Hujran, O., Al-Debei, M.M. \& Abu-Khajil, N., 2015, 'Green supply chain management and SMEs : A qualitative study', International Journal of Business Information Systems 18(2), 198-220. https://doi.org/10.1504/IJBIS.2015.067264

Huang, X., Tan, B.L. \& Ding, X., 2015, 'An exploratory survey of green supply chain management in Chinese manufacturing small and medium-sized enterprises', Journal of Manufacturing Technology Management 26(1), 80-103. https://doi. org/10.1108/JMTM-05-2012-0053

Isaksson, K., Bjorklund, M., Evangelista, P. \& Huge-Brodin, M., 2011, 'The challenge and adoption of green initiatives for transport and logistics service providers', in The 16th Annual LRN Conference, Southampton, September 07-09, 2015, pp. 1-10.

Jedliński, M., 2014, 'The position of green logistics in sustainable development of a smart green city', Procedia - Social and Behavioral Sciences 151(2014), 102-111. https://doi.org/10.1016/j.sbspro.2014.10.011

Karedza, G., Nyamazana, M., Mpofu, T. \& Makurumidze, S., 2014, 'An analysis of the obstacles to the success of SMEs in Chinhoyi Zimbabwe', European Journal of Business and Management 6(6), 38-42, viewed 10 January 2018, from www.iiste. org.

Kolk, A. \& Pinkse, J., 2008, 'A perspective on multinational enterprises and climate change: Learning from "an inconvenient truth"?', Journal of International Business Studies 39(8), 1359-1378, viewed 05 December 2017, from https://link.springer. com/article/10.1057/jibs.2008.61

Kumar, R., 2011, Research methodology: A step by step, 3rd edn., Sage, New Delhi. 
Lai, K.-H. \& Wong, C.W.Y., 2012, 'Green logistics management and performance: Some empirical evidence from Chinese manufacturing exporters', Omega 40(3), 267282. https://doi.org/10.1016/j.omega.2011.07.002

Lin, C. \& Ho, Y., 2010, 'Determinants of green practice adoption for logistics companies in China', Journal of Business Ethics 98(1), 67-83.

Makanyeza', C. \& Dzvuke, G., 2015, 'The influence of innovation on the performance of small and medium enterprises in Zimbabwe', Journal of African Business 16(12), 198-214. https://doi.org/10.1080/15228916.2015.1061406

Mangla, S.K., Kumar, P. \& Barua, M.K., 2015, 'Risk analysis in green supply chain using fuzzy AHP approach: A case study', Resources, Conservation and Recycling 104(2015), 375-390. https://doi.org/10.1016/j.resconrec.2015.01.001

Manyani, O., Hove, N., Mudzura, M. \& Chiriseri, L., 2014, 'An investigation into venture financing: A case study on small to medium scale enterprises in Bindura urban, Zimbabwe', Elite Research Journal of Accounting and Business Management 2(2), 10-25.

Maree, K., 2016, First steps in research, Van Schaik Publishers, Pretoria.

Masurel, E., 2007, 'Why SMEs invest in environmental measures: Sustainability evidence from small and medium-sized printing firms', Business Strategy and the Environment 16(3), 190-201.

Ministry of Energy and Power Development, National Energy Policy, 2017, viewed 19 July 2018, from http://www.energy.gov.zw/index.php/downloads\#

Musanzikwa, M., 2014, 'Managing small to medium enterprises suppliers in developing countries: A case of SMEs in Harare, Zimbabwe', Science Journal of Business and Management 2(1), 35. https://doi.org/10.11648/j.sjbm.20140201.15

Nyahunzvi, D.K., 2014, “'Greening” Gweru urban tourist lodges: Low levels of ecoliteracy, green awareness and actions', African Journal of Hospitality, Tourism and Leisure 3(1), 1-13.

Parker, C., Redmond, J. \& Simpson, M., 2009, 'Review of interventions to encourage SMEs to make environmental improvements', Environment and Planning C: Government and Policy 27(2), 279-301.

Parliament of Zimbabwe, 2002, Environmental Management Act 20:27, viewed 17 February 2018, from http://extwprlegs1.fao.org/docs/pdf/zim47834.pdf

Piaralal, K.S., Nair, S.R., Yahya, N. \& Karim, J.A., 2015, 'An integrated model of the likelihood and extent of adoption of green practices in small and medium sized logistics firms', American Journal of Economics 5(2), 251-258. https://doi. org/10.5923/c.economics.201501.32

Rao, P. \& Holt, D., 2005, 'Do green supply chains lead to competitiveness and economic performance?', International Journal of Operations \& Production Management 25(9), 898-916. https://doi.org/10.1108/01443570510613956
Research Continental-Fonkom and FinMark Trust, 2012, FinScope MSME survey Zimbabwe 2012, Finscope, Harare, Zimbabwe.

Sanchez, M.T. \& Lafuente, R., 2010, 'Defining and measuring environmental consciousness', Revista Internacional de Sociologia (RIS) 68(3), 731-755.

Šatanová, A. \& Sedliačiková, M., 2014, 'Quality controlling for small and medium-size enterprises', Annals of Warsaw University of Life Sciences-SGGW. Forestry and Wood Technology 49(4), 211-220.

Sbihi, A. \& Eglese, R.W., 2010, 'Combinatorial optimisation and green logistics', Annals of Operations Research 175(1), 159-175. https://doi.org/10.1007/s10479-0090651-z

Small Enterprise Development Corporation (SEDCO), 2011, 'Annual report', in Entrepreneurship, viewed 06 March 2018, from www.sedco.co.zw

Seroka-Stolka, O., 2014, 'The development of green logistics for implementation sustainable development strategy in companies', Procedia - Social and Behaviora Sciences 151, 302-309. https://doi.org/10.1016/j.sbspro.2014.10.028

Seroka-Stolka, O., 2016, 'Green initiatives in environmental management of logistics companies', Transportation Research Procedia 16, 483-489. https://doi. org/10.1016/j.trpro.2016.11.045

Speranza, M.G., 2018, 'Trends in transportation and logistics', European Journal of Operational Research 264(3), 830-836. https://doi.org/10.1016/j. ejor.2016.08.032

Srivastava, S., 2007, 'Green supply-chain management: A state-of-the-art literature review', International Journal of Management Reviews 9(1), 53-80, viewed 12 January 2018, from http://onlinelibrary.wiley.com/ doi/10.1111/j.1468-2370.2007.00202.x/full

Ubeda, S., Arcelus, F.J. \& Faulin, J., 2011, 'Green logistics at Eroski: A case study', International Journal of Production Economics 131(1), 44-51. https://doi. org/10.1016/j.ijpe.2010.04.041

Wu, H. \& Dunn, S.C., 1995, 'Environmentally responsible logistics systems', International Journal of Physical Distribution \& Logistics Management 25(2) 20-38. https://doi.org/10.1108/09600039510083925

Xuezhong, C., Linlin, J. \& Chengbo, W., 2011, 'Business process analysis and implementation strategies of greening logistics in appliances retail industry', Energy Procedia 5, 332-336. https://doi.org/10.1016/j.egypro.2011.03.056

Zaman, K. \& Shamsuddin, S., 2017, 'Green logistics and national scale economic indicators: Evidence from a panel of selected European countries', Journal of Cleaner Production 143, 51-63. https://doi.org/10.1016/j.jclepro.2016.12.150

Zhang, G. \& Zhao, Z., 2012, 'Green packaging management of logistics enterprises', Physics Procedia 24(2), 900-905. https://doi.org/10.1016/j.phpro.2012.02.135 